\title{
UTVRĐIVANJE DIMENZIONALNOSTI I MEĐUSOBNOG ODNOSA VARIJABLI KLASIČNE INTELIGENCIJE I EMOCIONALNE INTELIGENCIJE KAO SPOSOBNOSTI I KAO OSOBINE LIČNOSTI U LATENTNOM PROSTORU
}

\author{
Dario Vučenović \\ Hrvatski studiji Sveučilišta u Zagrebu \\ Borongajska cesta 83d, 10 000, Zagreb \\ dvucenovi@hrstud.hr \\ Ljerka Hajncl \\ Zavod za vještačenje, profesionalnu rehabilitaciju i zapošljavanje osoba s invaliditetom \\ Područni ured Osijek, Tadije Smičiklasa 2, 31000 Osijek \\ ljerka.hajncl@os.ht.hr
}

\begin{abstract}
Sažetak
Prezentiranim istraživanjem nastojala se otkriti dimenzionalnost i faktorska struktura latentnog prostora ispitivanih varijabli (verbalna i neverbalna inteligencija, emocionalna inteligencija kao sposobnost i kao osobina ličnosti) s ciljem detektiranja je li emocionalna inteligencija dio kognitivnih sposobnosti ili osobina ličnosti. Istraživanje je provedeno na uzorku od 500 ispitanika dobnog raspona od 15 do 65 godina. Uzorak je podijeljen na tri dobne skupine: mlađu (15-25 godina), srednju (26-45 godina) i stariju (46-65 godina). Rezultati su pokazali da se u sve tri dobne skupine ekstrahira prvi faktor koji predstavlja kognitivne sposobnosti i zasićen je mjerom EI kao sposobnost. To su potvrdili koeficijenti kongruencije između tri dobne skupine. U mlađoj i srednjoj dobnoj skupini ekstrahirana su dodatna dva faktora, pri čemu drugi faktor predstavlja EI kao ličnost, a treći EI kao sposobnost. Koeficijent kongruencije je pokazao da treći faktor između mlađe i srednje dobne skupne nije kongruentan. U starijoj dobnoj skupini ekstrahiran je samo jedan dodatni faktor, povrh faktora kognitivnih sposobnosti i na njemu su se smjestile mjere EI kao sposobnost i EI kao osobina ličnosti. Ključni nalaz istraživanja jest da je EI kao sposobnost značajno povezana s verbalnim faktorom, tj. kristaliziranom inteligencijom te da postoji razlika u emocionalnom procesiranju u funkciji dobi. Sve navedeno upućuje na to da je emocionalna inteligencija vjerojatno jedna od kognitivnih sposobnosti, a ne osobina ličnosti.
\end{abstract}

Ključne riječi: emocionalna inteligencija, inteligencija, sposobnost, osobine ličnosti. 


\section{UVOD}

Emocionalnu inteligenciju kao konstrukt uveli su u psihološku literaturu Mayer i Salovey 1990-ih godina (Salovey i Mayer, 1990; Mayer, Caruso i Salovey, 2016), a tijekom godina je operacionalizirana kao sposobnost percepcije, procjene i ekspresije emocija; sposobnost uviđanja i uopćavanja osjećaja koji facilitiraju mišljenje; sposobnost razumijevanja emocija i znanje o emocijama te sposobnost regulacije emocija koja podupire emocionalni i intelektualni razvoj (Mayer i Salovey, 1997; Vučenović i Hajncl, 2018). S obzirom na to da definicija emocionalne inteligencije uključuje različite vještine i sposobnosti u kontekstu doživljavanja, ponašanja i procesiranja emocija, četiri navedene sposobnosti poredane su po složenosti s obzirom na psihološke procese koji su im podlozi: od jednostavnijih (percepcija i ekspresija emocija) do složenih (svjesnost, refleksivnost i regulacija emocija) (Mayer i Salovey, 1997; Vučenović, 2012). Autori konceptualizacije navode kako novija istraživanja pokazuju da emocionalna inteligencija označava svojevrsni $g$ faktor $\mathrm{u}$ kontekstu rješavanja problema emocionalnog predznaka. Za razliku od ranije, više se ne očekuje da će specifični mentalni faktori uključeni u EI nužno koincidirati sa specifičnim područjima rješavanja emocionalnih problema predloženim u originalnom modelu (Mayer i sur., 2016).

Navedena konceptualizacija emocionalne inteligencije je više ili manje prihvaćena, ali u literaturi ne postoji slaganje o samoj prirodi procesa u podlozi emocionalne inteligencije. Suvremena psihologija suočava se i pokušava razriješiti nedoumicu je li emocionalna inteligencija sastavni dio kognicije ili prava pozadina emocionalnih procesa leži u osobinama ličnosti. Petrides i Furnham (2000) predložili su da postoji navedena razlika u psihološkim procesima u podlozi emocionalne inteligencije ovisno o načinu mjerenja, a iz koje proizlazi da su emocionalna inteligencija kao sposobnost i emocionalna inteligencija kao osobina ličnosti dva odvojena konstrukta. Ova podjela postoji i danas i podupiru je brojna istraživanja (Petrides, 2016a). Nastavno na predloženu distinkciju proizlazi da se emocionalna inteligencija kao osobina ličnosti proučava u kontekstu psihologije ličnosti te se kao konstelacija bihevioralnih dispozicija i samoprocjena povezanih s prepoznavanjem, procesiranjem i korištenjem emocionalnih informacija (Pertides i Furnham, 2003; Costa i Takšić, 2016) mjeri ljestvicama samoprocjene vlastitih emocionalnih sposobnosti. Metodološki nedostaci ljestvica samoprocjene (socijalno poželjno odgovaranje, davanje (ne)svjesno iskrivljenih odgovora) jedan je od osnovnih problema pristupu emocionalnoj inteligenciji kao osobini ličnosti. Također, vrlo malen broj mjera samoprocjena EI razvijen je u okviru jasnog teorijskog modela, a još manje ih ima empirijsku osnovu, zbog čega je i validacija tih mjera empirijski gotovo nemoguća (Petrides, 2016b). Drugi ozbiljan metodološki problem jest što je način testiranja emocionalne inteligencije kao osobine ličnosti sličniji modelu ispitivanja klasične inteligencije, zbog čega pristup emocionalnoj inteligenciji kao sposobnosti sve više i dobiva na važnosti. Sličnost s modelima klasične inteligencije je u konstrukciji i validaciji testova koji proizlaze iz postavke da je emocionalna inteligencija sposob- 
nost zapažanja, obrade i korištenja informacija koje imaju emocionalni predznak. Emocionalna inteligencija je time određena kao jedna od kategorija kognitivnih sposobnosti pa se kao klasična inteligencija i treba mjeriti testovima maksimalnog učinka. Za razliku od testova klasične inteligencije, u testovima EI kao sposobnosti ne postoji jedan objektivan točan odgovor, već se točni odgovori određuju na temelju jednog od kriterija bodovanja (konsenzus i mišljenje stručnjaka). Ovo svakako predstavlja svojevrsni metodološki izazov budući da se bodovanja prema različitim kriterijima preklapaju, ali samo u određenoj mjeri (Petrides, 2016b), a ne postoji apsolutni i objektivni algoritam ili formula za procjenu točnih odgovora emocionalnog sadržaja. Razlog je u tome što se EI formira na temelju kulturalnih i socijalnih iskustava pojedinca i ovisi i o intrapersonalnim i o društvenim standardima i uvjerenjima (Emmerling i Boyatzis, 2012; Costa i Takšić, 2016).

Roberts, Zeidner i Matthews (2001; Vučenović i Hajncl, 2018) zagovaraju tezu da je Cattell-Horn-Carroll teorija o fluidnoj i kristaliziranoj inteligenciji plauzibilna za objašnjavanje emocionalne inteligencije. EI se promatra kao jedan aspekt kristalizirane inteligencije jer psihološki procesi u podlozi kristalizirane inteligencije korespondiraju s onima u podlozi ukupnog emocionalnog procesiranja, ponašanja i doživljavanja. To potkrepljuju nalazi kako su mjere EI pozitivno povezane s mjerama verbalne inteligencije koja raste s dobi i s iskustvom i kao takva predstavlja mjeru kristalizirane inteligencije (Vučenović, 2012). Uočeno je i da emocionalna inteligencija raste $u$ funkciji dobi i razvoja, posebno ulaskom u stadij formalnih operacija po Piagetu, za koji je zaslužan snažan zamah u razvoju intelektualnokognitivnih funkcija (Berk, 2007). Vučenović i Hajncl (2018) navode da razvoj apstraktnog mišljenja omogućuje lakše razumijevanje emocija.

Zagovaratelji EI kao osobine ličnosti navode da EI nije dio kognicije, nego je povezana s motivacijom, osobinama ličnosti (ekstraverzija, neuroticizam i ugodnost, prema Vučenović, 2012), raspoloženjem, socijalnom adaptacijom, socijalnim i interpersonalnim vještima i sl. Petrides (2016b) navodi i facete poput asertivnosti, samopouzdanja, empatije, optimizma, upravljanja stresom, impulzivnosti i sl. EI se konceptualizira u terminima Bandurine samoefikasnosti i naziva se emocionalna samoefikasnost, koja je dio ličnosti, a označava svjesnost vlastitih emocija i mogućnost njihove regulacije (Petrides, 2016b). Slično kao i kod EI kao sposobnosti, Petrides i Furnham (2003) napominju da je EI osobina ličnosti drugog reda, zbog čega se i ne očekuju visoke korelacije s robusnim konceptima poput neuroticizma ili ekstraverzije. Hajncl i Vučenović (2013) napominju da unutar ovog pristupa treba razdvojiti autore koji EI koncipiraju u terminima ličnosti, ali koja je bliska kogniciji (Goleman, 1997; Bar-On, 2000; Hajncl i Vučenović, 2013) od autora koji EI vide kao čistu osobinu ličnosti (Petrides i Furnham, 2000; Petrides, 2011; Hajncl i Vučenović, 2013).

Postoji struja autora koja navodi još jedan ozbiljan problem kod mjerenja EI, neovisno o tome razmatra li se kao osobina ličnosti ili kao sposobnost. Radi se o procjeni valjanosti pojedinih mjernih instrumenata, koja predstavlja najveće ograni- 
čenje u objašnjavanju EI (Miners, Côté i Lievens, 2018). Valjanost EI mjera obično se procjenjuje u terminima konstruktne valjanosti, psihometrijskih karakteristika testa ili povezanosti za koju se pretpostavlja da postoji između ispitivanih konstrukata. Navedeni autori smatraju kako bi se valjanost trebala procjenjivati u terminima mentalnih procesa u pozadini odgovora. Valjanost se tada ne bi u ovolikoj mjeri razlikovala između pojedinih mjera EI, što bi omogućilo sustavnije i preciznije istraživanje EI. Costa i Takšić (2016) slažu se da je problem valjanosti različitih mjera EI evidentan, ali napominju da je ovo područje istraživanja tek u začecima $i$ da se istraživači i autori EI mjera suočavaju s pronalaženjem kriterija za procjenu valjanosti, pri čemu su se u dosadašnjim istraživanjima EI mjere kao osobine ličnosti pokazale lošijima od EI mjera kao sposobnost.

Sukladno svemu navedenom, cilj istraživanja bio je determinirati strukturu faktorskog prostora i pozicioniranje ispitivanih varijabli (EI kao sposobnost, EI kao ličnost, neverbalna i verbalna inteligencija), kao i podudaranje faktora između mlađe, srednje i starije dobne skupine.

\section{METODA}

\section{Sudionici i postupak}

U istraživanju su sudjelovali ispitanici širokog raspona kronološke dobi (1565). Budući da je istraživački nacrt bio transverzalnog tipa, ispitanici su podijeljeni u različite dobne skupne koje korespondiraju kognitivnom i emocionalnom razvoju. Istraživanje je provedeno u srednjim školama, Zavodu za zapošljavanje i Obiteljskom centru Zadarske županije, bilo je anonimno, s napomenom da se rezultati isključivo koriste u znanstvene svrhe te je provedeno u malim skupinama ispitanika $(2-10)$.

\section{Instrumenti}

Upitnik emocionalne kompetencije (UEK-45, Takšić, 2002)

Upitnik emocionalne inteligencije sastoji se od 45 čestica i ima 3 subskale: sposobnost uočavanja i razumijevanja emocija; sposobnost izražavanja i imenovanja emocija i sposobnost upravljanja emocijama. Pouzdanost ukupnog testa je zadovoljavajuća (Cronbach $\alpha=0,88-0,92$ ), kao i pouzdanosti pojedinih subskala. S obzirom na umjerenu korelaciju između subskala, ukupan rezultat formira se kao mjera opće emocionalne kompetentnosti.

UEK-45 mjeri se ljestvicama samoprocjene te su sukladno očekivanjima u provjeri konvergentne i diskriminantne valjanosti dobivene umjerene do visoke kore- 
lacije s mjerama EI kao osobine ličnosti (SEIS, TAS-20). Rezultati na UEK mjera su EI kao osobine ličnosti.

\section{Test rječnika emžocija (TRE-102, Takšić, Harambašić i Velemir, 2004)}

Test rječnika emocija ima 102 čestice i mjeri EI kao sposobnost. Instrument ima jedan točan odgovor jer su pitanja koncipirana kao traženje sinonima za predloženu riječ emocionalnog karaktera i ponuđenih 6 opcija. Sve riječi u testu odabrane su uz pomoć eksperata i postoji jedan točan odgovor prema Anićevu rječniku. Ispitivanja su pokazala da ovaj instrument ima umjerenu korelaciju i jednakih je propozicija kao subtest Rječnika Kalifornijskih testova mentalne zrelosti, što upućuje na povezanost s kristaliziranom inteligencijom. Također, ispitivanja su pokazala zadovoljavajuću pouzdanost $(\alpha=0,91)$.

\section{Mayer-Salovey-Caruso Emotional Intelligence Test (MSCEIT, Salovey i sur.,} 2001; Mayer i sur., 2003)

MSCEIT je mjera EI kao sposobnosti jer direktno mjeri sposobnost pojedinca za rješavanje problema emocionalnog predznaka, čime EI procjenjuje na sličan način kao i klasični testovi inteligencije. Temeljni zadatak ispitanika je da prepoznaju emocije u facijalnoj ekspresiji i prezentiranim slikama; da se stave u određeno raspoloženje i u njemu rješavaju prezentirane probleme; nađu uzroke različitim emocijama i razumiju kako se emocije razvijaju te odrede optimalan način uključivanja emocija u vlastito mišljenje u situacijama koje se tiču njih samih ili drugih ljudi. Postoji osam subskala (po 2 za svaki od 4 stupnja emocionalnog procesiranja navedenog u uvodu). U ovom istraživanju korištene su skale D i H koje zahvaćaju sposobnost reflektivnog upravljanja emocijama (učinkovito korištenje emocija pri mišljenju vezanom za rješavanje problema u situacijama koje se odnose na pojedinca i na druge ljude). MSCEIT ima zadovoljavajuću konvergentnu i divergentnu valjanost, pouzdanosti subskala su zadovoljavajuće $(\alpha=0,86-0,93)$, a faktorizacijom prvog i drugog reda dobiva se faktor iskustva i faktor rezoniranja. Glavni metodološki problem ovog instrumenta jest $u$ korištenju kriterija pri određivanju točnih odgovora, posebno kod subskala koje obuhvaćaju procese mišljenja višeg reda (kao u našem slučaju sa skalom D i H) jer je u evaluaciju točnih odgovora potrebno uzeti u obzir i varijable osobnih i društvenih standarda. Kako bismo odredili točan odgovor, koristili smo konsenzus kriteriji, i to mod (točan odgovor je onaj odabran od strane najvećeg broja ispitanika) i prošireni mod (osim najčešćeg odgovora, kod mod kriterija kao točan odgovor uzimaju se i vrijednosti ispred i iza najčešće odabranog odgovora).

\section{Cattelov test inteligencije (CTI)}

CTI mjeri $g$ faktor, odnosno rezultat predstavlja mjeru opće inteligencije, neverbalnog je tipa zbog čega rezultat nije opterećen kulturalnim, verbalno-jezičnim i obrazovnim varijablama. Temeljni zadatak ispitanika je uočiti i zaključiti o relacijama na prezentiranim oblicima i slikama. Validacija instrumenta (subskala 2) poka- 
zuje zadovoljavajuću pouzdanost pri različitim metodama evaluacije $(\alpha=0,67-84)$, visoku konstruktnu valjanost s $g$ faktorom i visoku kriterijsku valjanost s drugim instrumentima koji mjere opći faktor inteligencije (npr. Ravennove progresivne matrice, WISC, WAIS i dr.). Rezultat na CTI predstavlja mjeru fluidne inteligencije.

\section{DAT - baterija općih sposobnosti - verbalno rasuđivanje (DAT-VR)}

DAT je instrument općih sposobnosti, odnosno baterija testova koja mjeri inteligenciju u različitim područjima kognitivnog rasuđivanja. Sastoji se od tri subskale namijenjene za detekciju razine prosuđivanja u: verbalnom, numeričkom i apstraktnom području. U ovom istraživanju korišten je Test verbalnog rasuđivanja, koji mjeri sposobnost razumijevanja odnosa između riječi te predstavlja mjeru kristalizirane inteligencije. Pouzdanost Testa verbalnog rezoniranja nešto je manja od druga dva subtesta $(\alpha=0,72-0,77)$ i testa primijenjenog u cijelosti, ali je i dalje zadovoljavajuća.

Podaci su prikupljeni u okviru znanstveno-istraživačkog projekta pod vodstvom prof. dr. sc. Vladimira Takšića naziva Razvoj i kroskulturalna provjera konstrukta emocionalne inteligencije (MB: 009-0342618-2657). U projektu je sudjelovao međunarodni tim stručnjaka te ga je u razdoblju 2002.-2005. financiralo MZOŠ. Cilj projekta bio je validacija postojećih mjernih instrumenata EI i razvijanje novih te je dobivena i suglasnost autora MSCEIT-a za njegovu aplikaciju u znanstvene svrhe.

\section{REZULTATI}

U Tablici 1 prikazane su međusobne korelacije ukupnog uzorka između mjera neverbalne i verbalne inteligencije, mjera emocionalne inteligencije kao osobine ličnosti i kao sposobnost te dobi.

Inspekcijom Tablice 1 može se vidjeti da su neverbalna i verbalna mjera IQ povezane te da su obje mjere klasične IQ povezane s Testom rječnika emocija, $s$ time da je korelacija viša s mjerom verbalne inteligencije. Radi se o srednjoj veličini efekta $(r=0,35)$. Veća povezanost TRE-102 i DAT-VR ide u prilog tezi da je EI dio kognitivnih sposobnosti jer korelira s mjerom verbalne inteligencije koja korespondira Cattellovoj kristaliziranoj inteligenciji. Visina korelacije govori u prilog da je EI jedna od kognitivnih sposobnosti, a ne dio intelekta.

Subskale Upitnika emocionalne kompetentnosti međusobno su umjereno povezane $(r=0,35-0,51)$ te nisko povezane s MSCEIT-om. MSCEIT je pozitivno povezan i s TRE-102, kao mjerom EI kao sposobnost jer mjere istu koncepciju EI konstrukta, a niske i neznačajne korelacije između varijabli koje mjere EI kao sposobnost i EI kao ličnost upućuje na to da su dvije koncepcije EI odvojeni konstrukti. Tome se pridružuje i nalaz da ni jedna mjera EI kao osobine ličnosti nije povezana s mjerama IQ, posebno verbalnim faktorom, odnosno kristaliziranom inteligencijom, dok mjere EI kao sposobnost jesu. 
Tablica 1. Interkorelacijska matrica ispitivanih mjera na ukupnom uzorku $(\mathrm{N}=500)$

\begin{tabular}{lcccccccc}
\hline Var & CTI aps & DAT-VR & UEK-PR & UEK-II & UEK-UR & MSCEIT & TRE-102 & Dob \\
\hline CTI aps & 1,00 & & & & & & & \\
DAT-VR & $0,53^{*}$ & 1,00 & & & & & & \\
UEK-PR & 0,00 & 0,06 & 1,00 & & & & & \\
UEK-II & $-0,00$ & 0,01 & $0,45^{*}$ & 1,00 & & & & \\
UEK-UR & 0,05 & 0,06 & $0,32^{*}$ & $0,40^{*}$ & 1,00 & & & \\
MSCEIT & 0,01 & 0,03 & $0,15^{*}$ & $0,26^{*}$ & $0,19 *$ & 1,00 & & \\
TRE-102 & $0,17^{*}$ & 0,35 & 0,07 & $0,13^{*}$ & $-0,04$ & $0,27^{*}$ & 1,00 & \\
Dob & $-0,34^{*}$ & $-0,02$ & $-0,10^{*}$ & $0,23^{*}$ & $-0,11^{*}$ & $0,11^{*}$ & $0,35^{*}$ & 1,00 \\
\hline
\end{tabular}

${ }^{*} p<0,05$

Legenda: CTI aps - Cattellov neverbalni test inteligencije; DAT-VR - DAT baterija: subtest Verbalno rasuđivanje; UEK-PR - Percepcija i razumijevanje emocija; UEK-II - Izražavanje i imenovanje emocija; MSCEIT - Mayer-Salovey-Caruso Emotional Intelligence Test; TRE-102 - Test rječnika emocija.

Dob je negativno povezana s mjerom neverbalne IQ i sa subskalama Percepcija i razumijevanje emocija i Upravljanje i reguliranje emocija (UEK-45). To znači da stariji ispitanici postižu lošije rezultate na CTI-u, što je očekivano jer je mjereni neverbalni faktor inteligencije mjera fluidne inteligencije. Stariji ispitanici daju niže samoprocjene na skalama Percepcija i razumijevanje emocija te Upravljanje i reguliranje emocija. To ne mora nužno značiti da su u ovom segmentu lošiji od mlađih ispitanika, već da su realniji u procjenama. Ostale mjere EI su nisko, ali značajno pozitivno povezane s dobi. Ovakav rezultat je očekivan jer EI raste s dobi.

Ukupan uzorak podijeljen je na tri dobne skupine sukladno relevantnim razvojnim fazama: 15-25 godina, 26-45 godina i 46-65 godina. Na svakoj dobnoj skupini provedena je FA i izračunati Tuckerovi koeficijenti kongruencije u svrhu utvrđivanja podudarnosti dobivenih faktorskih struktura.

Tablica 2 pokazuje da su faktorskom analizom dobivena tri faktora u mlađoj dobnoj skupini. Na prvom faktoru nalaze se neverbalna i verbalna mjera inteligencije te Test rječnika emocija. TRE-102 je zasićen i na 3 faktoru na kojem se smjestio i MSCEIT, također mjera EI kao sposobnost. Na drugom faktoru nalaze se mjere EI kao osobine ličnosti, preciznije sve tri subskale UEK-45. Dobivena faktorska struktura upućuje na odvojenost konstrukata EI kao sposobnost i EI kao osobina ličnosti te da je EI jedna od kognitivnih sposobnosti. Razlog saturacije TRE-102 u faktoru klasične inteligencije jest u njegovoj strukturalnoj sličnosti s testovima verbalne inteligencije s kojima i najviše korelira ( $\mathrm{r}=0,35$; Tablica 1).

Tablica 3 pokazuje faktorizaciju ispitivanih varijabli na uzorku ispitanika srednje dobi. Dobivena je faktorska struktura od tri faktora: na prvom faktoru su verbalna i neverbalna inteligencija te TRE-102, na drugom faktoru su sve tri subskale 
Tablica 2. Rezultati faktorske analize (varimax) ortogonalna rotacija ispitivanih mjera na poduzorku 15-25 godina $(N=165)$

\begin{tabular}{lcccc}
\hline Var & $\mathrm{F} 1$ & $\mathrm{~F} 2$ & $\mathrm{~F} 3$ & $\mathrm{~h}^{2}$ \\
\hline CTI aps & $0,836^{*}$ & 0,031 & $-0,069$ & 0,70 \\
DAT-VR & $0,887^{*}$ & 0,20 & $-0,036$ & 0,79 \\
TRE-102 & $0,647^{*}$ & $-0,055$ & $0,569^{*}$ & 0,75 \\
MSCEIT & $-0,085$ & 0,147 & $0,888^{*}$ & 0,82 \\
UEK-PR & 0,022 & $0,758^{*}$ & 0,154 & 0,60 \\
UEK-II & $-0,062$ & $0,789^{*}$ & 0,237 & 0,68 \\
UEK-UR & 0,061 & $0,726^{*}$ & $-0,200$ & 0,57 \\
Objašnjena varijanca & 1,919 & 1,749 & 1,239 & 4,907 \\
Proporcija objašnjene var. & 27,410 & 24,986 & 17,693 & 70,098 \\
\hline
\end{tabular}

"p $p<0,05$

Tablica 3. Rezultati faktorske analize (varimax) ortogonalna rotacija ispitivanih mjera na poduzorku 26-45 godina $(N=174)$

\begin{tabular}{lcccc}
\hline Var & $\mathrm{F} 1$ & $\mathrm{~F} 2$ & $\mathrm{~F} 3$ & $\mathrm{~h}^{2}$ \\
\hline CTI aps & $0,813^{*}$ & $-0,146$ & $-0,177$ & 0,71 \\
DAT-VR & $0,876^{*}$ & 0,031 & $-0,028$ & 0,77 \\
TRE-102 & $0,623^{*}$ & 0,075 & $0,374^{*}$ & 0,53 \\
MSCEIT & $-0,033$ & 0,040 & $0,941^{*}$ & 0,89 \\
UEK-PR & $-0,034$ & $0,787^{*}$ & $-0,003$ & 0,62 \\
UEK-II & 0,043 & $0,826^{*}$ & $-0,041$ & 0,69 \\
UEK-UR & $-0,054$ & $0,764^{*}$ & 0,146 & 0,61 \\
Objašnjena varijanca & 1,823 & 1,915 & 1,081 & 4,819 \\
Proporcija objašnjene var. & 26,048 & 27,353 & 15,442 & 68,843 \\
\hline
\end{tabular}

${ }^{*} p<0,05$

UEK-45 i na trećem faktoru su TRE-102 i MSCEIT. Uočavamo ponovno saturaciju TRE-102 u prvom i trećem faktoru, s time da je zasićenje manje na trećem faktoru kod ispitanika srednje dobi. To se pokazalo i u ispitivanju kongruentnosti faktorske strukture, pri čemu se prvi i drugi faktor podudaraju, a treći ne.

Inspekcijom Tablice 4 vidimo da su se u starijoj dobnoj skupini faktorskom analizom dobila samo dva faktora. Na prvom faktoru nalaze se neverbalna i verbalna inteligencija te Test rječnika emocija. Na drugom faktoru smjestili su se MSCEIT i sve tri skale UEK-45. Kod starijih ispitanika EI kao sposobnost i EI kao osobina 
Tablica 4. Rezultati faktorske analize (varimax) ortogonalna rotacija ispitivanih mjera na poduzorku 46-65 godina $(N=161)$

\begin{tabular}{lccc}
\hline Var & $\mathrm{F} 1$ & $\mathrm{~F} 2$ & $\mathrm{~h}^{2}$ \\
\hline CTI aps & $0,768^{*}$ & 0,288 & 0,67 \\
DAT VR & $0,759^{*}$ & 0,105 & 0,59 \\
TRE 102 & $0,724^{*}$ & $-0,054$ & 0,53 \\
MSCEIT & 0,122 & $0,608^{*}$ & 0,39 \\
UEK PR & 0,149 & $0,633^{*}$ & 0,42 \\
UEK II & 0,103 & $0,817^{*}$ & 0,68 \\
UEK UR & $-0,047$ & $0,789^{*}$ & 0,63 \\
Objašnjena varijanca & 1,740 & 2,158 & 3,898 \\
Proporcija objašnjene var. & 24,855 & 30,832 & 55,687 \\
\hline
\end{tabular}

${ }^{*} p<0,05$

ličnosti saturirani su u jednom zajedničkom faktoru, dok je TRE-102 isključivo zasićen u faktoru klasične inteligencije.

Postojanje jednog faktora EI vjerojatno je odraz stila i načina odgovaranja kod starijih ispitanika, posebno na MSCEIT-u. Koeficijenti kongruencije faktorskih struktura upućuju na međusobno podudaranje prvog faktora u svim dobnim skupinama, dok se drugi faktor kod starijih ispitanika ne podudara niti s mlađim niti s ispitanicima srednje dobi. Razlog za to je vjerojatno starija dob, što ima utjecaja na kognitivno i emocionalno procesiranje te shvaćanja zadatka u testnoj situaciji.

\section{RASPRAVA}

Trenutačno ne postoji konsenzus o prirodi i podlozi emocionalne inteligencije, pri čemu neki autori smatraju da je EI sposobnost, a neki da je osobina ličnosti.

U ovom istraživanju prvi faktor u svim dobnim skupinama je faktor kognitivnih sposobnosti, a saturacija TRE-102 na faktoru kognitivnih sposobnosti je očekivana jer se na njemu nalazi verbalni faktor inteligencije mjeren DAT-VR-om. Valja napomenuti da se to odnosi i na činjenicu da TRE-102, za razliku od ostalih testova EI kao sposobnost ima jedan točan odgovor poput klasičnih testova inteligencije i ne suočava se metodološkim izazovima vezanim za kriterije određivanja točnih odgovora. To ide u prilog tezi da se EI treba promatrati kao jednu od kognitivnih sposobnosti jer je dio kristalizirane inteligencije koju predstavlja verbalni faktor $(\mathrm{r}=0,35$, objašnjeno je preko $12 \%$ zajedničke varijance; Tablica 1$)$.

Pozicioniranje TRE-102 u treći faktor s MSCEIT-om u mlađoj i srednjoj dobnoj skupini očekivan je jer su u istraživanju korištene D i H subskale MSCEIT-a koje obuhvaćaju više razine emocionalnog funkcioniranja i korespondiraju TRE-102, a 
oba instrumenta mjere EI kao sposobnost. Odvajanje subskala UEK-45 u zasebni, drugi faktor kod mlađe i srednje dobne skupine u faktor EI kao osobina ličnosti potvrđuje tezu da su EI kao sposobnost i EI kao osobina ličnosti dva odvojena konstrukta te da je EI kao osobina ličnost neovisna o kognitivnim sposobnostima. Razlika između mlađe i srednje dobne skupine postoji u visini saturacije TRE-102 na trećem faktoru. Niža saturacija TRE-102 na trećem faktoru kod srednje dobi u odnosu na mlađu, mogla bi biti odraz očekivanog porasta kristalizirane inteligencije mjerene DAT-VR-om kao i očekivanim porastom EI u srednjoj dobi. Koeficijenti kongruencije potvrdili su da se jedino treći faktor ne podudara između mlađe i srednje dobne skupine. Razlog tome je vjerojatno nešto niža pouzdanost skala MSCEIT-a, široki dobni raspon unutar svake dobne skupine te broj ispitanika unutar svake skupine.

U starijoj dobnoj skupini ekstrahirana su samo dva faktora. Prvi faktor predstavlja klasičnu inteligenciju (verbalnu i neverbalnu) te mjeru EI kao sposobnost (TRE-102). Drugi faktor predstavlja emocionalnu inteligenciju i kao osobinu ličnosti (subskale UEK-45) i kao sposobnost (MSCEIT) te se ne podudara s drugim faktorom u ostale dvije dobne skupine. Ovakav nalaz je i očekivan jer stariji ispitanici procesiraju intelektualne podražaje i emocionalni sadržaj na značajno drugačiji način. Pozicioniranje subskala UEK-45 i MSCEIT-a na drugom faktoru, dakle kombinacija mjera EI kao sposobnost i EI kao osobine ličnosti možemo objasniti na način da u starijoj skupini ispitanika ovaj faktor ne označava emocionalnu inteligenciju, već emocionalnu kompetenciju (Vučenović, 2012). Tijekom primjene testa shvaćanje zadatka starijih na MSCEIT-u drugačije je od onog kako bi se trebalo odgovarati. Stariji ispitanici tretiraju MSCEIT kao mjeru samoprocjene i u pravilu odgovaraju što bi oni učinili u prezentiranoj situaciji, umjesto da odaberu odgovor za koji misle da je točan. Vučenović i Hajncl (2018) napominju kako sadržaj zadataka na mjerama EI nije u potpunosti primjeren starijoj dobnoj skupini jer su instrumenti konstruirani i validirani na mlađim dobnim skupinama $i$ ističu problem kriterija bodovanja i određivanja točnih odgovora.

Drugačije procesiranje emocionalnog sadržaja kod starijih osoba podupire nalaz da je prosječno raspoloženje kod starijih osoba pozitivnije u odnosu na mlađe koji imaju tendenciju negativnijih raspoloženja te da stariji pokazuju bolju regulaciju emocija negativnog predznaka u odnosu na mlađe (Carstensen, Pasupathi, Mayr i Nesselroade, 2000). To možemo djelomično objasniti nalazom prema kojem mlađi naginju detaljnijem procesiranju negativnih emocionalnih sadržaja od starijih (Rozin i Royzman, 2001; Vučenović, 2012), ali i time da stariji negativne emocionalne sadržaje sagledavaju s pozitivnije strane, što i je jedna od odrednica EI. Važan neuroznanstveni nalaz povezan je s neuralnim procesiranjem negativno obojenog emocionalnog sadržaja. Limbički sustav, preciznije amigdala sudjeluje u regulaciji emocionalnih i motivacijskih stanja (Tadinac i Hromatko, 2006), ali kod starijih ispitanika se pokazalo da se pri prezentaciji negativnih emocionalnih sadržaja gasi aktivnost amigdale koju preuzima medijalni prefrontalni korteks zadužen za 
donošenje odluka (Leclerc i Kensinger, 2011; Vučenović, 2012). Možemo zaključiti da se emocionalno procesiranje u slučaju negativnih emocionalnih informacija $u$ starijoj dobi odvija u višim moždanim strukturama, u odnosu na mlađu dob u kojoj su niže moždane strukture osnova obrade emocionalnih informacija. Neproporcionalno povećanje prefrontalnog korteksa kod ljudi u odnosu na ostale primate pozicioniralo je homo sapiensa na najviši stupanj filogenetske ljestvice u kognitivnom razvoju i procesiranju (Tadinac i Hromatko, 2006). Roth i Dicke (2005) su u svom komparativnom istraživanju zaključili da je jedini prediktor za stupanj inteligencije broj neurona u korteksu te brzina neuronske aktivnosti, što dokazuje da su ljudi kao vrsta intelektualno najnapredniji i da se inteligencija veže za (prefrontalni) korteks. Aktiviranje prefrontalnog korteksa pri obradi negativnih emocija i supresija nižih moždanih struktura upućuje na povezanost EI, posebno viših razina EI (regulacija i refleksija emocija) s intelektualnim sposobnostima u funkciji dobi.

Dodatna podrška EI kao sposobnosti je i nalaz Bracketta i sur. (2006) koji stipulira da ljudi ne mogu procijeniti vlastitu inteligenciju ili druge sposobnosti i da metoda (samo)procjene takvih konstrukata nužno rezultira neželjenom varijancom koja je više povezana sa samopoštovanjem, samopouzdanjem, održavanjem slike o sebi, željama ispitanika i sl. i kao takva u ispitivanje EI preko samoprocjena unosi varijancu koja nema veze s konstruktom i koju ne možemo odstraniti.

Najvažniji nalaz ovog istraživanja je povezanost mjere EI kao sposobnost $\mathrm{i}$ verbalne IQ te postupno sve veća saturacija TRE-102 (EI kao sposobnost) na prvom kognitivnom faktoru koji je kongruentan u sve tri dobne skupne. To podupire tezu da se EI treba mjeriti testovima maksimalnog učinka jer je EI dio sposobnosti te da EI raste s dobi. Vučenović i Hajncl (2018) došli su do sličnog zaključka. Faktorizacija ispitivanih varijabli u dva faktora u starijoj dobnoj skupini upućuje na drugačije emocionalno procesiranje kod starijih ispitanika, a međusobno nepodudaranje trećeg faktora u mlađoj i srednjoj dobnoj skupini i drugog faktora kod starijih ispitanika upućuje na trend rasta EI kao sposobnosti u funkciji dobi, što nije slučaj s varijablama koje EI mjere kao osobinu ličnosti. Spomenuta povezanost EI s intelektualnim sposobnostima u funkciji dobi odnosi na kristaliziranu inteligenciju koja također raste s dobi i s iskustvom, za razliku od fluidne inteligencije koja bilježi znatan pad u funkciji dobi. Spomenuti pad dokazan je u ovom (Tablica 1), ali i u drugim istraživanjima (npr. Vučenović i Hajncl, 2018). Fluidnu inteligenciju mjerimo neverbalnim testovima inteligencije jer ovisi o temeljnim vještinama i brzini obrade informacija, dok verbalni faktor pokazuje sličan trend razvoja kao kristalizirana inteligencija jer ovisi o akumuliranom znanju, učenju i stjecanju (verbalnog) iskustva (Vučenović, 2012). Prezentirane nalaze podupiru i nalazi (npr. Vučenović i Hajncl, 2018) koji su potvrdili da je EI razvijenija kod ispitanika starije životne dobi, posebno na složenijim razinama EI te se slažu da su zadovoljeni kriteriji za definiranje EI kao sposobnost.

Istraživanjem smo uključili ispitanike širokog dobnog raspona (15-65 godina), što dosad nije bio slučaj, ali transverzalni tip nacrta predstavlja metodološki izazov i 
određene zadrške vezane za generalizaciju rezultata. Široki dobni raspon i relativno malen broj ispitanika vjerojatno je utjecao na relativno niske povezanosti između ispitivanih varijabli. Ispitivanjem emocionalne inteligencije kod starijih ne možemo zanemariti utjecaj neprilagođenosti mjernih instrumenata drugačijem emocionalnom funkcioniranju i procesiranju starijih ispitanika u odnosu na mlađu i srednju dob, najviše kod MSCEIT-a. Vučenović i Hajncl (2018) izvijestili su o sličnim ograničenjima u svom istraživanju. Isti autori predlažu da bi se u budućim istraživanjima točni odgovori trebali određivati po kriteriju slaganja s ostatkom grupe (konsenzus mod), ali za svaku dobnu skupinu zasebno (Vučenović i Hajncl, 2018).

Intenzivna digitalizacija u novije vrijeme nalaže dodatni oprez jer se mijenja način procesiranja najviših neuralnih struktura. Greenfield (2018) upozorava da izloženost društvenim mrežama usporava razvoj empatije i identiteta, pri čemu je empatija prepoznata kao važan dio emocionalne inteligencije (Ali, Sousa Amorim i Chamorro Premuzic, 2006). Spitzer (2018) navodi da djeca pod utjecajem pretjerane digitalizacije postaju nesocijalizirana i frustrirana te da su mlađe generacije socijalizirane drugačije od starijih zbog pretjerane izloženosti digitalnim medijima. Emocionalna inteligencija kao skup socijalnih iskustava te osobnih i društvenih standarda razlikuje se između kultura (Emmerling i Boyatzis, 2012; Costa i Takšić, 2016) i raste s verbalnim i socijalnim iskustvom, pri čemu je socijalizacija i interakcija s drugim članovima društva važan element EI (npr. Brody i Hall, 1993; Vučenović i Hajncl, 2018). Costa i Takšić (2016) napomenuli su važnost kulture i socijalnog konteksta za razvoj svih razina EI stoga tehnološke promjene i pretjerana digitalizacija u kulturi i društvu zasigurno utječu u nekoj mjeri i na razvoj EI.

Navedeni sistematski faktori koje imamo u dobnim kohortama u transverzalnom nacrtu, trebalo bi isključiti provođenjem longitudinalnog istraživanja koje bi pratilo jednu kohortu u razvojnoj perspektivi i uključilo veći broj ispitanika jer ne znamo točno na što i kako sve utječu. Vučenović i Hajncl (2018) slažu se oko provedbe longitudinalnog istraživanja, ali napominju da se ono ne primjenjuje često zbog nedostataka i vremena koje je potrebno za provedbu.

Valja napomenuti još jednu stvar, autori MSCEIT-a (Mayer i sur., 2016), a vezano za rečeno u uvodu kako bi se valjanost trebala procjenjivati na temelju procesa odgovora koje pokreće sposobnost u pozadini EI, revidirali su već navedeni model četiri razine vještina i sposobnosti EI. Prezentiran je nadograđeni model koji pretpostavlja svojevrsni $g$ faktor EI kao sposobnost koji naglašava sposobnost $u$ pozadini odgovora. Time uključuje nekoliko dodatnih područja rješavanja problema, što je u originalnom modelu bilo previđeno (Mayer i sur., 2016). Revidirani model dodaje emocionalnu procjenu, emocionalno predviđanje te osjetljivost na kulturalni kontekst (Mayer i sur., 2016). Autori (Mayer i sur., 2016) također spominju da Cattell-Horn-Carroll teorija nije dovoljna za objašnjavanje emocionalne inteligencije i uvode pojam vruće inteligencije (engl. hot intelligence) koju čine socijalna, osobna (personalna) i emocionalna inteligencija. U budućim istraživanjima trebalo bi znanstveno utvrditi koliko se revidirana koncepcija modela EI u kontek- 
stu MSCEIT-a razlikuje u odnosnu na originalnu i provjeriti valjanost i pouzdanost samog instrumenta.

Zaključno možemo reći da je i na temelju ovog istraživanja i na temelju prethodno navedenih istraživanja teza da je EI dio sposobnosti dobila više empirijske podrške od koncepta EI kao osobine ličnosti. EI kao sposobnost treba promatrati kao jedan od aspekata intelektualnih sposobnosti jer se priroda i procesi u podlozi procesiranja emocionalnih informacija i intelektualnog procesiranja ne preklapaju u potpunosti.

\section{LITERATURA}

Ali, F., Sousa Amorim, I. i Chamorro Premuzic, T. (2009). Empathy deficits and trait emotional Intelligence in psychopathy and Machiavellianism. Personality and Individual Differences, 47(7), 758-762. DOI: 10.1016/j.paid.2009.06.016

Bar-On, R. (2000). Emotional and social intelligence: insights from Emotional Quotient Inventory. U: R. Bar-On \& D. A. Parker (ur.), The handbook of emotional intelligence (str. 363-388). San Francisco: Jossey-Bass.

Berk, L. E. (2007). Psihologija cjeloživotnog razvoja. Jastrebarsko: Naklada Slap.

Brackett, M. A., Rivers, S. E., Shiffman, S., Lerner, N. i Salovey, P. (2006). Relating emotional abilities to social functioning: A comparison of self-report and performance measures of emotional intelligence. Journal of Personality and Social Psychology, 91, 780-795. DOI:10.1037/0022-3514.91.4.780

Brody, R. i Hall. A. J. (1993). Gender and Emotion. U: M. Lewis and J. Haviland, (ur.), Handbook of Emotions (str. 396-393). New York: Guilford Press.

Carstensen, L.L., Pasupathi, M., Mayr, U. i Nesselroade, J. R. (2000). Emotional experience in everyday life across the adult life span. Journal of Personality and Social Psychology, 79(4), 644-655. DOI: 10.1037//0022-3514.79.4.644

Costa, A.F.A i Takšić, V. (2016). Cross-cultural invariance of Emotional Skills and Competence Questionnaire between Portugal and Croatia. The Spanish Journal of Psychology, 19, 1-12. DOI: 10.1017/sjp.2016.33

Emmerling, R. J. i Boyatzis, R. (2012). Emotional and social intelligence competencies: Cross-cultural implications. Cross-Cultural Management: An International Journal, 19(1), 4-18. DOI: $10.1108 / 13527601211195592$

Goleman, D. (1997). Emocionalna inteligencija. Zagreb: Mozaik knjiga.

Greenfield, S. (2018). Promjene uma: Kako digitalne tehnologije utječu na naš mozak. Zagreb: Školska knjiga.

Hajncl, Lj. i Vučenović D. (2013). Emocionalna inteligencija: Modeli i mjerenje 20 godina poslije. Suvremena psihologija 16(1), 95-113.

Leclerc, C.M. i Kensinger, E.A. (2011). Neural processing of emotional pictures and words: A comparison of young and older adults. Developmental Neuropsychology, 36(4), 519538. DOI: $10.1080 / 87565641.2010 .549864$

Mayer, D., Salovey, P., Caruso, D.R. i Sitarenios G. (2003). Measuring Emotional Intelligence with the MSCEIT 2.0. Emotion, 3(1), 97-105. DOI: 10.1037/1528-3542.3.1.97 
Mayer, J.D. i Salovey, P. (1997). What is emotional intelligence? U: P. Salovey i D. Sluyter, (ur.), Emotional development and emotional intelligence: Implications for educators (str. 3-31). New York: Basic Books.

Mayer, J.D., Caruso, D.R. i Salovey, P. (2016). The Ability Model of Emotional Intelligence: PrinciplesandUpdates.EmotionReview,8(4),290-300.DOI:10.1177/1754073916639667

Miners, T.H., Côté, S. i Lievens, F. (2018). Assessing the Validity of EI Measures. Emotion Review, 10(1), 87-95. DOI: 10.1177/1754073917693688

Petrides, K. V. i Furnham, A. (2003). Trait Emotional Intelligence: Behavioral Validation in Two Studies of Emotion Recognition and Reactivity to Mood Induction. European Journal of Personality, 17(1) 39-57. DOI: 10.1002/per.466

Petrides, K.V. (2011). Ability and trait emotional intelligence. U: Chamorro-Premuzic, T., Furnham, A. i von Stumm, S. (ur.), The Blackwell-Wiley Handbook of Individual Differences (657-678). New York: Wiley.

Petrides, K.V. (2016a). Emotional Intelligence as Personality Trait. U: A. S. Antoniou i C. Cooper, (ur.), New Directions in Organizational Psychology and Behavioral Medicine (str. 139-147). New York: Routledge.

Petrides, K.V. (2016b). Four Thoughts on Trait Emotional Intelligence. Emotion Review, $8(4), 345$. DOI: $10.1177 / 1754073916650504$

Petrides, K.V. i Furnham, A. (2000). On the dimensional structure of emotional intelligence. Personality and individual differences, 29, 313-320. DOI: 10.1016/S01918869(99)00195-6

Roberts, R. D., Zeidner, M. i Matthews, G. (2001). Does Emotional Intelligence Meet Traditional Standards for an Intelligence? Some New Data and Conclusions. Emotion, 1(3), 196-231. DOI: 10.1037/1528-3542.1.3.196

Roth, G. i Dicke, U. (2005). Evolution of the Brain and Intelligence. Trends in Cognitive Sciences, 9(5), 250-257. DOI: 10.1098/rstb.2015.0180

Rozin, P. i Royzman, E.B. (2001). Negativity bias, negativity dominance, and contagion. Personality and Social Psychological Review, 5, 296-320. DOI: 10.1207/ S15327957PSPR0504 2

Salovey, P. i Mayer, J.D. (1990). Emotional intelligence. Imagination, Cognition and Personality, 9(3), 185-211. DOI: 0.2190/DUGG-P24E-52WK-6CDG

Salovey, P., Mayer, J.D., Caruso, D. i Lopez, P.N. (2001). Measuring emotional intelligence as a set of mental abilities with MSCEIT. U: S.L. Lopez i C.R. Snyder (ur.), Handbook of positive psychology assessment. Washington DC: American Psychological Association.

Spitzer, M. (2018). Digitalna demencija: kako mi i naša djeca silazimo s uma. Zagreb. Naklada Ljevak.

Tadinac, M. i Hromatko, I. (2006). Uvod u biološke osnove doživljavanja i ponašanja. Zagreb. Filozofski fakultet.

Takšić, V. (2002). Upitnici emocionalne inteligencije (kompetentnosti). U: K. LackovićGrgin, A. Bautović, V. Čubela i Z. Penezić (ur.), Zbirka psihologijskih skala i upitnika (str. 27-45). Zadar: Filozofski fakultet.

Takšić, V., Harambašić, D. i Velemir, B. (2004.). Emotional Vocabulary Test as an attempt to measure the emotional intelligence ability - understanding emotion aspect. Rad prezentiran na The 28th International Congress of Psychology, Beijing, 08-13. August. 
Vučenović, D. (2012). Emocionalna inteligencija i obrada emocionalnih sadržaja u različitoj dobi. (Neobjavljena doktorska disertacija). Filozofski fakultet, Zagreb.

Vučenović, D. i Hajncl, Lj. (2018). Efekti dobi na međusobni odnos verbalnih i neverbalnih sposobnosti te emocionalne inteligencije. Suvremena psihologija 21(2), 121-139. DOI: 10.21465/2018-sp-212-01

\title{
DETERMINING LATENT DIMENSIONS AND RELATIONSHIP BETWEEN INTELLIGENCE, ABILITY EMOTIONAL INTELLIGENCE AND TRAIT EMOTIONAL INTELLIGENCE
}

\begin{abstract}
Summary
The presented research aimed to establish the dimensionality and factorial structure of measured variables: nonverbal and verbal intelligence, ability emotional intelligence and trait emotional intelligence in order to answer the question of whether $\mathrm{EI}$ is an ability or a trait. The research was conducted on 500 participants, ranging from 15 to 65 years of age. The sample was divided into three age groups: youth (15-25 years), middle-age (26-45 years), and elderly ( $46-65$ years). The results indicated that in all three age groups the first extracted factor was a cognitive factor, saturated with an ability EI measure. This was confirmed by coefficients of congruence between all three age groups. In the youth and middle-age group, an additional two factors were extracted. The second factor represented trait EI and the third factor represented ability EI. The coefficient of congruence indicated that the third factor in youth and middle age isn't congruent. In the elderly group, apart from affirmed first factor representing intelligence, one additional factor was extracted. The second factor in the elderly group represented trait EI and ability EI, combined. The most important result of this research is a significant correlation between ability EI and verbal intelligence (crystallized IQ) and a difference in emotional processing depending on the age group. All these findings lead us to conclude that EI is probably one of the cognitive abilities, not a trait.
\end{abstract}

Key words: emotional intelligence, intelligence, ability, traits.

Primljeno; 09. 07. 2019. 
